\section{AL-AZHAR}

Assiut Dental Journal
The Official Publication of The

Faculty of Dental medicine.

Al-Azhar Assiut Uniuersity.

AADJ, Vol. 3, No. 1, April (2020) - PP. 43:51

ISSn 2682-2822

\title{
Evaluation of Socket Preservation Using A Synthetic Nanocrystalline Hydroxyapatite
}

\author{
Mostafa E. Elkhatib*, Tarek M. Abd El-Samad
}

Codex : 06/2020/04

Aadj@azhar.edu.eg

\section{KEYWORDS}

Socket Preservation, CBCT,

Nano Hydroxyapatite,

Collagen Membrane,

3-D Measurement.

1. Department of Oral and Maxillofacial surgery, Faculty of Dental Medicine(Boys), Cairo, Al-Azhar University, Egypt.

* Corresponding Author e-mail: mostafaelkhatib@azhar.edu.eg

\begin{abstract}
Aim: This study was designed to evaluate the socket preservation using a synthetic nanocrystalline hydroxyapatite followed by collagen membrane. Subjects and methods: Fourteen patients were selected from Oral and Maxillofacial clinic of the Faculty of Oral and Dental Medicine, Al-Azhar University, Cairo, Boys. Extraction of tooth of lower premolar area was done to all participants. Then they were divided into 2 groups, where 7 sockets were preserved and the 7 were kept as control. After tooth extraction in the test group nanobone putty form was grafted into the socket. An additional covering was performed by a collagen membrane. A cone beam computed tomography (CBCT) radiograph at 3 and 6 months were done to assess bone density and socket dimensions. All readings were recorded and analyzed statistically. Results: Among the study group, there is a high statistically significant difference between the three measurements (soon after extraction, after 3- and 6- months from operation) as regards the mean of bone density and the three dimensions .Conclusion: Nano hydroxyapatite together with collagen membrane to seal the socket accelerates the formation of bone filling in the extracted bony socket
\end{abstract}

\section{INTRODUCTION}

Postextraction alveolar ridge resorption is a common phenomenon that impairs placement of dental implant and may cause esthetic problems in prosthetic dentistry ${ }^{(1,2)}$.

Resorption of buccal/lingual walls of the extraction site occurs in two overlapping phases. During the early phase of remodeling, the bundle bone undergoes resorption and replaced by woven bone.Since the crest of the buccal bone is comprised solely of bundle bone, this remodeling will result in substantial vertical reduction of the buccal bone crest. Moreover, resorption occurs from the outer surfaces of both bone walls ${ }^{(3-6)}$. 
It has been shown that autogenous bone grafts are the gold standard for the treatment of segmental bone defect but the surgical morbidity as well as bone sources limitation and the need for the second surgery have reduced their frequent use ${ }^{(7)}$. Moreover, allografts bone has been suggested to be used but probably immunological responses restrict its use ${ }^{(8)}$.

Different material has been used in order to solve these problems; synthetic biocompatible bone substitutions that become the most widely used. These materials consist of calcium, phosphate, ceramics and organic materials; it can provide a stable scaffold for appropriate bone response and subsequent bone repair ${ }^{(9)}$.

NanoBone developed by Artoss* company, is basically nanocrystalline HA embedded in silica gel matrix. Features such as interconnecting pores on the nanoscale, the open $\mathrm{SiOH}$ or $\mathrm{SiO}$ groups of polysilicic acid, has large internal surface, and the high porosity that may related to the calcification process observed within the implantation bed ${ }^{(10,11)}$. While the HA component is responsible for osteoconductive properties, the silica component is believed to induce connective tissue formation, osteoblast proliferation, bone matrix mineralization, and calcification, thus combining osteoconductive and osteoinductive properties ${ }^{(11-13)}$.

This phenomenon is associated with the rearrangement of the silica matrix, which could be observed in vivo ${ }^{(13,14)}$.

Based on the observations gained from several clinical studies that confirming the properties of nanocrystalline HA. This study is designed to evaluate the outcomes of using nanocrystalline hydroxyapatite in socket preservation ${ }^{(15-17)}$.

\section{AIM OF THE STUDY}

The aim of the present study was to evaluate the Socket preservation using a synthetic nanocrystalline hydroxyapatite followed by collagen membrane.

\section{PATIENT AND METHODS}

In this study, 14 patients ( 7 males and 7 females) with age range was between 20 to 38 years were selected from Oral and Maxillofacial clinic of the Faculty of Oral and Dental Medicine, Al-Azhar University, Cairo, Boys. Extraction of tooth of lower premolar area was done to all participants. Then they were divided into 2 groups, where 7 sockets were preserved and the other 7 were kept as control.

\section{Selection criteria:}

- Inclusion criteria: Patient with decayed lower premolar with adequate bone at least 3-4 $\mathrm{mm}$ beyond the apex of the tooth

- Exclusion criteria: Soft tissue recession at the extraction site and un-cooperative patients.

\section{A -Preoperative phase}

All patients underwent pre-operative clinical examination: Patients' data were collected; name, gender and age, medical and dental histories were taken. Also, all patients underwent periapical radiograph to exclude any pathosis and evaluate the dimensions of the socket

\section{B -Operative phase}

- After local anesthesia had been administered, sulcular incisions were given around the premolars with a sharp instrument such as a No.15 scalpel.

- Periotome was used to dissect the attached fibers. The blade had to be angled at 20 degrees to ensure that the tip of the periotome was within the crest of the alveolar bone.

\section{Artoss, Rostock, Germany; Dentaurum Implants, Ispringen, Germany*}


- The instrument was inserted first in the gingival sulcus and then in the periodontal ligament space. The periotome was moved repeatedly in a mesio-distal direction, along the circumference of the root.

- Finally, the extraction of the tooth was performed with forceps without distorting or damaging the alveolar bone.

- After extraction, all patients underwent CBCT imaging.

- After tooth extraction in the control group, the soft and hard tissues were curetted and sutured (Fig 1).

- In the test group, nanobone putty form was grafted into the socket up to $2 \mathrm{~mm}$ apical to the soft tissue margin.

- An additional covering of the surgical site was performed by means of a collagen membrane (Hypro-Sorb F) (fig.2)

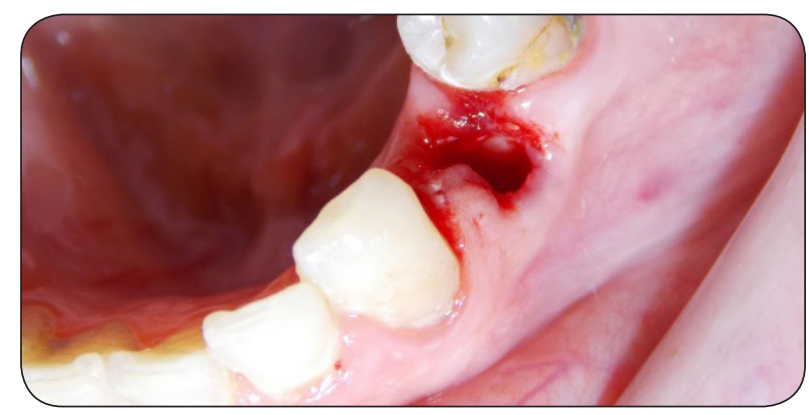

Fig. (1) Lower left first premolar socket after ataumatic extraction (among control group)



Fig. (2) Nanobone putty form and resorbable collagen membrane adaptation

\section{C-Postoperative phase}

\section{Postoperative medications:}

The standard postsurgical instructions were given to the patient. A list of drugs was then prescribed to the patients as following: Amoxicillin (Amoxil ${ }^{\mathrm{TM}}$ ) $500 \mathrm{mg}$ capsules (t.d.s) for 7 days / Metronidazole (Flagyl@) $500 \mathrm{mg}$ tablets (t.d.s) for 7 days / Ibuprofen (Brufen®) 600 mg tablets (t.d.s) for 3 days and then when necessary / Chymotrypsin + trypsin $\left(\right.$ Alphintern $\left.{ }^{\circledR}\right)$ tablets (t.d.s) half an hour before meals for 7 days. Patients were instructed to rinse their mouths twice daily with a solution of $0.1 \%$ chlorhexidine gluconate (Antiseptol solution) for 10 days.

\section{Postoperative instructions:}

$1^{\text {st }}$ day instructions: All patients informed to do the following:

- Bite on the pack for $30 \mathrm{~min}$. and then remove it.

- Cold fomentation (10 minutes on, every 30 minutes off.)

- Never to eat hard, spicy foods or drink hot drinks.

- Never to suck anything (include smoking, Shisha)

- Never use any mouth wash.

$2^{\text {nd }}$ day instructions: Patients instructed to follow the 1st day instructions but without cold fomentation and they washed their mouth by $0.1 \%$ chlorhexidine gluconate mouth wash \& sterile saline.

\section{D- Follow up phase}

Bone density and socket dimensions were evaluated after the treatment by using a cone beam computed tomography (CBCT) radiograph at 3 and 6 months following treatment, to assess bone density and vertical, horizontal and bucco-lingual dimensions 
- Bone Density Assessment: By using beam CBCT software, the change in density of the graft was calculated in Hounsfield units (HU). The mean values of bone density were recorded. This process was repeated at each interval postoperative follow up.

- Socket dimensions: By using beam CBCT software, the socket dimensions were calculated in millimeters (mm). Vertical line was set parallel to the tooth axis of the tooth before extraction, and the horizontal line was set perpendicular to the vertical line. The bucco-lingual ridge heights were measured from the most apical point of the alveolar socket to the height of the crest. The mean values of the three dimensions were recorded. This process was repeated at each interval postoperative follow up.

\section{Statistical analysis:}

Data were represented as mean and standard deviation. Independent sample t-test of significance and chi square test were used when comparing between the two groups. Repeated measures analysis of variance (ANOVA) test was used to compare numeric variables within the studied group of patients. Data were analyzed using SPSS. Result was considered statistically significant if the p- value was less than 0.05 .

\section{RESULTS}

There were 14 patients included in this study ]. They were classified into 2 groups, 7 patients in the study group and 7 patients in the control group. Patients' age ranged from 20 to 39 years, the mean average age was 31.64 years old in the study group and 30.81 years in the control group.

There is a highly statistically significant difference between the two groups as regards the bone density either at 3 months or 6 months of follow up.

There is a high statistically significant difference between the study and control group as regards the amount of changes occur in the measurements of bone density, vertical, horizontal and bucco-lingual dimensions soon after extraction and after 6 months from treatment $(\mathrm{P}<0.01)$. (table 1)

Table (1) Amount of changes occur in the measurements of bone density, vertical, horizontal and buccolingual dimensions soon after extraction and after 6 months from treatment for the study and control group

\begin{tabular}{|l|c|c|c|c|c|c|}
\hline \multicolumn{2}{|c|}{$\begin{array}{c}\text { Change from on admission } \\
\text { to } 6 \text { months after operation }\end{array}$} & Group I & Group II & \multirow{2}{*}{ Test value } & P-value & Sig. \\
\cline { 3 - 6 } & Mean \pm SD & $-1.48 \pm 0.93$ & $-2.99 \pm 0.35$ & 4.041 & 0.002 & HS \\
\hline Vertical & Mean \pm SD & $-0.65 \pm 0.29$ & $-1.78 \pm 0.49$ & 5.222 & 0.000 & HS \\
\hline Horizontal & Mean \pm SD & $-0.83 \pm 0.49$ & $-2.77 \pm 0.38$ & 8.217 & 0.000 & HS \\
\hline Bucco-lingual & Mean \pm SD & $1216.14 \pm 157.32$ & $907.71 \pm 69.8$ & 4.741 & 0.000 & HS \\
\hline Density & & & & & & \\
\hline
\end{tabular}




\section{DISCUSSION}

Tooth extraction is a traumatic procedure initiating a complex cascade of biochemical and histologic events that inevitably lead to a reduction of alveolar bone and soft tissue. ${ }^{(18)}$ These changes at the extraction site may be due to the loss of periodontal ligament fibers, bundle bone, and loss of blood supply. These morphologic changes pose significant challenges in restorative treatment, as soft tissue recession and buccal plate resorption define the anatomical profile of the socket and may narrow the viable treatment options. ${ }^{(19)}$ Accordingly, reconstruction of resorbed alveolar ridges has been a goal and a challenge for clinicians to create an anticipated foundation for implant placement to optimize the outcomes. ${ }^{(20)}$

As the present study suggested, successful alveolar ridge preservation procedures may reduce or eliminate the need for future ridge augmentation. This was consistent with recent data published by Nevins et al. who emphasized on the significance of bone grafting following tooth extraction in preserving buccal plate integrity and in consequence, alveolar ridge dimensions for ideal implant treatment. ${ }^{(21)}$

Allograft, xenograft, and alloplastic materials, along with the autogenous bone, have been utilized in preserving the alveolar ridge. During post extraction healing, vertical and horizontal bone loss is expected, yet the use of grafting materials can provide dimensional stability to the alveolar ridge. Bone healing and subsequent new bone formation after grafting take place via osteogenesis, osteoinduction and/or osteoconduction. ${ }^{(22)}$

One of the used substances is Hydroxyapatite which is a good candidate for bone substitutes due to its chemical and structural similarity to bone minerals. Nanocrystalline HA exhibit greater surface area and are expected to have better bioactivity than coarser crystals. Osteoconductivity, solubility and mechanical reliability of the HA can be promoted by controlling its particle size and structural morphology in the order of nanoscale. ${ }^{(23)}$
In the present study, preservation of Sockets was done immediately after extraction of lower premolar area among the study group. Preservation was done by using nanobone putty form which was directly applied into the defect.

In the present study, an additional covering of the surgical site was performed by means of a collagen membrane. This was in full agreement with results of Kim et al who observed that there is higher bone density of the grafted bone among the group received bone grafting, combined with collagen membranes, results in less bone resorption than bone grafting alone. ${ }^{(24)}$ In addition, this was consistent with Lekovic et al. who compared the outcome of alveolar ridge preservation using a bioabsorbable membrane to extraction alone. At 6 months, they found significantly less crestal bone loss and less horizontal ridge in the membrane group than in the control. ${ }^{(25)}$

To promote a fair comparison between groups, special attention was given in this study to site selection during subject recruitment. Only lower premolars were included to evaluate extraction sockets of similar size, bone quality, and anatomy. This concept was done also by Neiva et al who justify the use of one site extraction in their study to minimize variables and strengthen the results obtained. (96) The use of nanobone in this study based on its ability to chemically bind to bone, without inducing toxicity or inflammation and stimulating bone growth through a direct action on osteoblasts. This was in full agreement with Huang et al who did in vitro assessment of the biological response to nano hydroxyapatite and found that nHA-sprayed substrates were able to support the attachment and the growth of human osteoblast-like cells. These results indicate that nHA crystals may be suitable for intraosseous implantation and offers the potential to formulate enhanced composites for biomedical applications. ${ }^{(26)}$

In the present study, a change of the alveolar bone level was detected radiographically using 
consecutive pre- and post-operative radiographs. Periapical radiograph was done before extraction to exclude any pathosis and evaluate the bone height, mesio-distal width and depth of the socket. CBCT scans were done immediately after extraction and at 3- and 6-months following treatment to assess the following parameters: bone density and vertical, horizontal and buccolingual dimensions. The results were compared with another similar control group, who didn't get socket preservation after tooth extraction. This was in full agreement with Silva et al. who prove that the CBCT images can become a reliable tool for bone density assessment. ${ }^{(27)}$

Results of the present study shows that, in the control group, without socket preservation, the reduction in vertical dimensions after 3 months was by $2.35 \pm 0.34$, and after 6 months was by $2.99 \pm$ 0.35 . While the reduction in the horizontal dimensions after 3 months was about by $1.11 \pm 0.42$ and after 6 months was by $1.78 \pm 0.49$. Moreover, the reduction in the buccolingual dimensions after 3 months was about by $1.42 \pm 0.27$ and after 6 months was by $2.77 \pm 0.38$. These results were consistent with a systematic review which studied the effect of socket preservation therapies following tooth extraction in non-molar regions in humans and showed that, in natural healing after extraction, a reduction in width ranging between 2.6 and $4.6 \mathrm{~mm}$ and in height between 0.4 and $3.9 \mathrm{~mm}$ was observed (28) Lekovic also showed that, following tooth extraction, the rate of residual ridge resorption is related to the time extended since the tooth was removed. ${ }^{(29)}$

This concept is further assured by Schropp et al who evaluated the tissue changes after extraction of a premolar or molar in 46 patients in a 12-month period. The results demonstrated that major changes of an extraction site occurred during 1 year after tooth extraction. When examining the premolar area only, a loss of alveolar ridge width of $45 \%$ was reported, of which about third occurred in the first 12 weeks. ${ }^{(30)}$ Although, A recently published systematic review reported a greater horizontal alveolar ridge reduction than vertical bone loss at 6 months. ${ }^{(31)}$
Also, Zaffe et al used dissolution of aqueous nanocrystalline hydroxyapatite and applied it to post-extractive sites. They showed that the use of nanocrystalline hydroxyapatite as bone regenerating material leads to the formation of a highly suitable implant support consisting exclusively of bone in less than 12 months, i.e. in a remarkably short time. ${ }^{(32)}$

The result of the present study is also consistent with an article published by Araujo et al. who demonstrated that the placement of a biomaterial in an extraction socket will enhance bone modeling and compensate the marginal ridge contraction. ${ }^{(33)}$

Another study recommends that the use of nanobone in extractions operations and bone fractures lead to speed healing. This study was carried out on dogs who were treated with nano hydroxyapatite to seal the socket after simple atraumatic extraction of lower 2nd premolar. It was concluded that nanobone graft accelerates the formation of bone filling the extracted bony socket and preserved three dimensions of the extracted bony socket. ${ }^{(34)}$

On the other hand, one study has shown that ridge preservation does not completely prevent bone loss, it aids in reducing the extent of that loss. ${ }^{(35)}$

\section{CONCLUSION}

The outcome of the present study concluded that, after atraumatic extraction of the premolar tooth, using nano hydroxyapatite together with collagen membrane to seal the socket accelerates the formation of bone filling in the extracted bony socket, increasing its density and preserving its three dimensions.

\section{REFERENCES}

1. Hoffmann O, Bartee BK, Beaumont C, Kasaj A, Deli G, Zafiropoulos G-G. Alveolar bone preservation in extraction sockets using non-resorbable dPTFE membranes: a retrospective non-randomized study. Journal of periodontology. 2008;79(8):1355-69. 
2. Schropp L, Wenzel A, Kostopoulos L, Karring T. Bone healing and soft tissue contour changes following singletooth extraction: a clinical and radiographic 12-month prospective study. International Journal of Periodontics \& Restorative Dentistry. 2003;23(4):313-23.

3. Araújo MG, Sukekava F, Wennström JL, Lindhe J. Ridge alterations following implant placement in fresh extraction sockets: an experimental study in the dog. Journal of clinical periodontology. 2005;32(6):645-52.

4. Araújo MG, Lindhe J. Dimensional ridge alterations following tooth extraction. An experimental study in the dog. Journal of clinical periodontology. 2005;32(2):212-8.

5. Trombelli L, Penolazzi L, Torreggiani E, Farina R, Lambertini E, Vecchiatini R, et al. Effect of hydroxyapatitebased biomaterials on human osteoblast phenotype. Minerva stomatologica. 2010;59(3):103-15.

6. Irinakis $\mathrm{T}$, Tabesh M. Preserving the socket dimensions with bone grafting in single sites: an esthetic surgical approach when planning delayed implant placement. Journal of Oral Implantology. 2007;33(3):156-63.

7. Cottrell DA, Wolford LM. Long-term evaluation of the use of coralline hydroxyapatite in orthognathic surgery. Journal of oral and maxillofacial surgery. 1998;56(8):935-41.

8. Gazdag AR, Lane JM, Glaser D, Forster RA. Alternatives to autogenous bone graft: efficacy and indications. JAAOS-Journal of the American Academy of Orthopaedic Surgeons. 1995;3(1):1-8.

9. Sculean A, Barbé G, Chiantella GC, Arweiler NB, Berakdar M, Brecx M. Clinical evaluation of an enamel matrix protein derivative combined with a bioactive glass for the treatment of intrabony periodontal defects in humans. Journal of periodontology. 2002;73(4):401-8.

10. Gerber T, Traykova T, Henkel K-O, Bienengraeber $\mathrm{V}$. Development and in vivo test of sol-gel derived bone grafting materials. Journal of sol-gel science and technology. 2003;26(1-3):1173-8.

11. Gerber T, Holzhüter $\mathrm{G}$, Knoblich B, Dörfling $\mathrm{P}$, Bienengräber V, Henkel K-O. Development of bioactive sol-gel material template for in vitro and in vivo synthesis of bone material. Journal of Sol-Gel Science and Technology. 2000;19(1-3):441-5.

12. Kang Y-M, Kim K-H, Seol Y-J, Rhee S-H. Evaluations of osteogenic and osteoconductive properties of a non-woven silica gel fabric made by the electrospinning method. Acta Biomaterialia. 2009;5(1):462-9.
13. Porter AE, Patel N, Skepper JN, Best SM, Bonfield W. Effect of sintered silicate-substituted hydroxyapatite on remodelling processes at the bone-implant interface. Biomaterials. 2004;25(16):3303-14.

14. Götz W, Gerber T, Michel B, Lossdörfer S, Henkel KO, Heinemann F. Immunohistochemical characterization of nanocrystalline hydroxyapatite silica gel (NanoBone ${ }^{\circledR}$ ) osteogenesis: a study on biopsies from human jaws. Clinical Oral Implants Research. 2008;19(10):1016-26.

15. Canullo L, Dellavia C. Sinus lift using a nanocrystalline hydroxyapatite silica gel in severely resorbed maxillae: histological preliminary study. Clinical implant dentistry and related research. 2009; 11(s1):e7 - e13.

16. Stübinger S, Ghanaati S, Orth C, Hilbig U, Saldamli B, Biesterfeld S, et al. Maxillary sinus grafting with a nanostructured biomaterial: preliminary clinical and histological results. European Surgical Research. 2009;42(3): $143-9$.

17. Bienengräber V, Gerber T, Henkel K-O, Bayerlein T, Proff $\mathrm{P}$, Gedrange T. The clinical application of a new synthetic bone grafting material in oral and maxillofacial surgery. Folia morphologica. 2006;65(1):84-8.

18. Caplanis N, Lozada JL, Kan JY. Extraction defect assessment, classification, and management.J Calif Dent Assoc. 2005;33(11):853-63.

19. Elian N, Cho SC, Froum S, Smith RB, Tarnow DP, “A simplified socket classification and repair technique," Practical Procedures \& Aesthetic Dentistry, 2007; 19 (2): 99-104.

20. Khojasteh A, Behnia H, Shayesteh YS, Morad G, Alikhasi M. Localized bone augmentation with cortical bone blocks tented over different particulate bone substitutes: a retrospective study. Int J Oral Maxillofac Implants. 2012; 27(6):1481-93

21. Nevins M, Camelo M, Paoli S, et al. A study of the fate of the buccal wall of extraction sockets of teeth with prominent roots. Int J Periodontics Restorative Dent 2006; 26(1): 19-29.

22. Jambhekar, S., Kernen, F., \& Bidra, A. S. Clinical and histologic outcomes of socket grafting after flapless tooth extraction: a systematic review of randomized controlled clinical trials. The Journal of prosthetic dentistry, 2015, 113(5), 371-382

23. Murugan R, Rao KP, Kumar TSS. Heatdeproteinated xenogeneic bone from slaughterhouse waste: Physico-chemical properties. Bull Mater Sci 2003; 26(5): 523-8 
24. Kim SH, Kim DY, Kim KH, Ku Y, Rhyu IC, Lee YM. The efficacy of a double-layer collagen membrane technique for overlaying block grafts in a rabbit calvarium model. Clinical oral implants research. 2009; 20(10): 1124-32.

25. Lekovic V, Camargo PM, Klokkevold PR, Weinlaender M, Kenney EB, Dimitrijevic B, Nedic M. Preservation of alveolar bone in extraction sockets using bioabsorbable membranes. J Periodontol. 1998;69(9):1044-9.

26. J.Huang, S. M. Best, W. Bonfield, R.A. Brooks, N. Rushton, S. N. Jayasinghe, M. J. Edirisinghe. In vitro assessment of the biological response to nano-sized hydroxyapatite: Selected papers from the 18th European Conference on Biomaterials (ESB2003), Stuttgart, Germany, 2003. (Guest Editors: Michael Doser and Heinrich Planck). Journal of Materials Science: Materials in Medicine. 2004; 15(4): 10-17

27. Silva I, Freitas D, Ambrosano G, Boscolo F, Aleida S. Bonedensity: comparative of Hounsfield units in multislice and cone beam computed tomography. Braz Oral Res. 2012;26(6): 550-6

28. Ten Heggeler JM, Slot DE, Van der Weijden GA. Effect of socket preservation therapies following tooth extraction in non-molar regions in humans: A systematic review. Clinical oral implants research. 2011; 22(8):779-88.

29. Lekovic V, Kenney EB, Weinlaender M, et al. A bone regenerative approach to alveolar ridge maintenance following tooth extraction. Report of 10 cases. J Periodontol. 1997; 68(6):563-70.

30. Schropp L, Wenzel A, Kostopoulos L, Karring T. Bone healing and soft tissue contour changes following singletooth extraction: A clinical and radiographic 12-month prospective study. The International journal of periodontics \& restorative dentistry. 2003;23(4):313-23.

31. Tan W. L., Wong T. L. T., Wong M. C. M., and Lang N. P., "A systematic review of post-extractional alveolar hard and soft tissue dimensional changes in humans," Clinical Oral Implants Research. 2012; 23 (5):1-21.

32. Zaffe D, Traversa G, Mozzati M, Morelli F, D'Angeli G. Behavior of aqueous nanocrystalline hydroxyapatite in oral bone regeneration. Journal of applied biomaterials \& biomechanics : JABB. 2011, 9(1):19-25.

33. Araújo M, Linder E, Wennström J, Lindhe J. The influence of Bio-Oss Collagen on healing of an extraction socket: an experimental study in the dog. Int J Periodontics Restorative Dent. 2008;28(2):123-35.

34. W.Ghanem, I.Hussien, O.Kilany, I.ELlaboudy. Effect of Nano-Hydroxyapatite Graft on Socket Healing after Teeth Extraction. ARC Journal of Dental Science. 2016; 1(2): 4-1en Heggeler, J.M.; Slot, D.E.; van der Weijden, G.A. Effect of socket preservation therapies following tooth extraction in non-molar regions in humans: A systematic review. Clin. Oral Implants Res. 2011; 22(8): 779-788 
مجلة أسيوط لطب الأسنان

النشر الرسمي لكلية طب الأسنان جامعة الأزهر أسيوط لكاطية

\section{تقييم الحفاظ عله تجويف السنة بعد خلعها بإستخدام عظم إلهم الإمافم

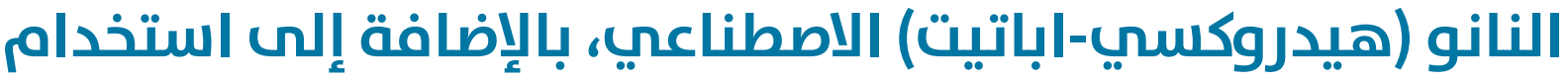 غشاء الكولاجين}

مصطفى الخطيب ، طارق عبدالصمد

1. قسمى جراحة الفه والوجه والفكين، كلية طب الاسنان (بنين ( ,القاهرة، جاهعة الأزهر، جهمورية مصر العربية

* البريد الالكترونى للباحث الرئيسى: MOSTAFAELKHATIB@AZHAR.EDU.EG

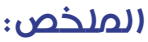

الهـدف: تهدف هذه الدراسـة الى تقييم الحفاظ على جُّويف السـنة بعد خلعها باستخدام عظم النانو (هيدروكسي-اباتيت) الاصطناعي.

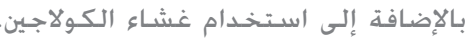

المواد والأسـاليب: تم اختيار 14 مريض في هذه الدراسة من عيادة جراحة الفم والوجه والفكين بكلية طب الأسنان، جامعة الأزهر، القاهرة.

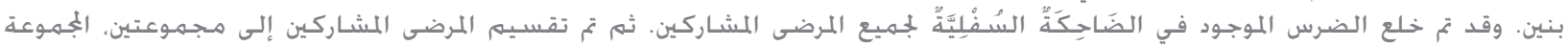

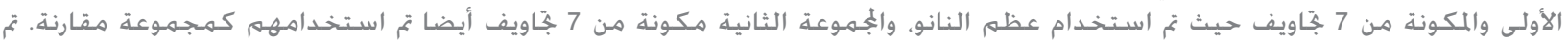

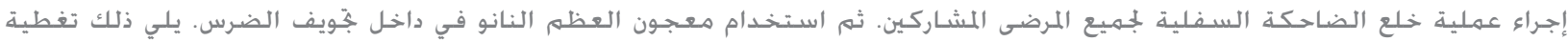

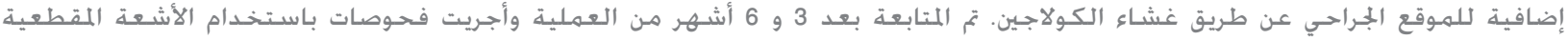



النتائج: أظهرت نتائج الدراسة أن هناك فروق ذات دلالة إحصائية فيما يتعلق بأبعاد ججويف الضرس وكثافة العظام في زيارات المتابعة المختلفة في مجموعة الدراسة.

الخلاصة: استخدام معجون العظم النانو بالإضافة الى غشاء الكولاجين يسرع من تكوين العظم في داخل جُويف الضرس بعد خلعه

الكلمات المفتاحية: الحفاظ على جُويف السنة بعد خلعها، عظم النانو (هيدروكسي-اباتيت)، غشاء الكولاجين, الأشعة المقطعية الخخروطية بالماسوب ، مقاسات ثلاثية الابعاد. 